\title{
Ichthyofauna from floodplain lakes of Reserva de Desenvolvimento Sustentável Piagaçu-Purus (RDS-PP), lower rio Purus
}

\author{
Bruno Ferezim Morales $^{1 *}{ }^{\circledR}$, Rafaela Priscila Ota ${ }^{\circledR}$, Victória Dandara Pereira e Silva $^{3}$, \\ Cláudia Pereira de Deus ${ }^{4}$ \\ ${ }^{1}$ Universidade Federal do Amazonas, Instituto de Ciências Exatas e Tecnologia em Itacoatiara, R. Nossa Sra. \\ do Rosário, Tiradentes, 69103-128, Itacoatiara, AM, Brasil \\ ${ }^{2}$ Instituto Nacional de Pesquisas da Amazônia, Programa de Pós-Graduação em Biologia de Água Doce e \\ Pesca Interior, Av. André Araújo, 2936, 69060-001, Manaus, AM, Brasil \\ ${ }^{3}$ Universidade do Estado do Amazonas, Graduação em Ciências Biológicas, Av. Darcy Vargas, 1.200, 69050- \\ 020, Manaus, AM, Brasil \\ ${ }^{4}$ Instituto Nacional de Pesquisas da Amazônia, Coordenação de Biodiversidade, Av. André Araújo, 2936. \\ 69060-001, Manaus, AM, Brasil \\ *Corresponding author: Bruno Ferezim Morales,e-mail: brunomorales@ufam.edu.br
}

MORALES, B.F., OTA, R.P, SILVA, V.D.P, DEUS, C.P. Ichthyofauna from floodplain lakes of Reserva de Desenvolvimento Sustentável Piagaçu-Purus (RDS-PP), lower rio Purus. Biota Neotropica. 19(4): e20190779. http://dx.doi.org/10.1590/1676-0611-BN-2019-0779

\begin{abstract}
The ichthyofauna of the rio Purus has been little investigated, especially in its lower portion, characterized by diverse aquatic environments, especially in flooded areas. We inventoried the ichthyofauna of floodplain lakes with different management efforts in Reserva de Desenvolvimento Sustentável Piagaçu-Purus (RDS-PP), which represent important resource for commercial fishing in North region, in the first illustrated inventory of the fish fauna from lower rio Purus. We surveyed 20 lakes, classified as open access (eight lakes) and protected (12 lakes) during 2009 low water levels. A total of 2,299 individuals were collected, represented by seven orders, 25 families and 74 species. Characiformes was the most representative order in number of species and families, followed by Siluriformes, Cichliformes, Gymnotiformes, Clupeiformes, and Osteoglossiformes. Most abundant and frequent species were Pygocentrus nattereri, Triportheus angulatus, Serrasalmus sp. " $2 \mathrm{n}=58$ ”, Pterygoplichthys gibbiceps, and Osteoglossum bicirrhosum. Protected lakes presented higher species richness compared to open access lakes. Similarly, protected lakes possessed 26 species occurring exclusively, with emphasis on Colossoma macropomum, an important species for fisheries due to its commercial importance. We added 44 new records of fish species for the lower rio Purus. Our results indicate the potential efficiency of zoning systems of open access and protected lakes established by local population and ruled by RDS-PP for fisheries management. Therefore, we strongly suggest its maintenance for conservation of ichthyofauna of floodplain lakes of lower rio Purus.
\end{abstract}

Keywords: Amazonian fish fauna, Conservation, Inventory, Neotropical.

\section{Ictiofauna de lagos de várzea da Reserva de Desenvolvimento Sustentável Piagaçu-Purus (RDS-PP), baixo rio Purus}

Resumo: A ictiofauna do rio Purus tem sido pouco investigada, especialmente em seu curso inferior, caracterizada pela diversidade de ambientes aquáticos, especialmente em áreas de inundação. Inventariamos a ictiofauna dos lagos de várzea com diferentes tipos de manejo na Reserva de Desenvolvimento Sustentável Piagaçu-Purus (RDS$\mathrm{PP})$, que representa importante recurso para pesca commercial na região Norte, no primeiro inventário ilustrado da fauna de peixes do baixo rio Purus. Amostramos 20 lagos classificados como de uso (oito lagos) e proteção (12 lagos), durante o período de águas baixas de 2009. Foi coletado um total de 2.299 indivíduos representados por sete ordens, 25 famílias e 74 espécies. Characiformes foi a ordem mais representativa em número de espécies e famílias, seguida por Siluriformes, Cichliformes, Gymnotiformes, Clupeiformes e Osteoglossiformes. As espécies mais abundantes e frequentes foram Pygocentrus nattereri, Triportheus angulatus, Serrasalmus sp. " $2 \mathrm{n}=58$ ", 
Pterygoplichthys gibbiceps e Osteoglossum bicirrhosum. Lagos de proteção apresentaram maior riqueza de espécies comparados aos lagos de uso. Similarmente, lagos de proteção possuíam 26 espécies ocorrendo exclusivamente nesta categoria, com ênfase no Colossoma macropomum, uma espécie importante para pesca devido ao seu valor comercial. Adicionamos 44 novos registros de espécies de peixes para o baixo rio Purus. Nossos resultados indicam a potencial eficácia do sistema de zoneamento de lagos de uso e proteção para o manejo da pesca estabelecido pela população local e regulamentada pela RDS-PP. Portanto, sugerimos fortemente sua manutenção para conservação da ictiofauna dos lagos de várzea do baixo rio Purus.

Palavras-chave: Fauna de peixes amazônicos, Conservação, Inventário, Neotropical.

\section{Introduction}

The Amazon basin is the largest and most diverse hydrographic system on Earth (Goulding et al. 2003), covering an area of over $8,000,000 \mathrm{~km}^{2}$ (Sioli 1984), comprising almost $20 \%$ of the total river water in the world (Reis et al. 2016). Diversity of ichthyofauna inhabiting the Amazon basin comprises 60 families, 529 genera, and almost 2,720 described species, from which more than $60 \%$ are endemic to the basin (Dagosta \& de Pinna 2019). However, this number might be underestimated, because new species descriptions are increasing fish species richness abruptly (Hoorn \& Wesselingh 2010, Dagosta \& de Pinna 2017).

The Western Amazon (or Lowland Amazon) is drained by whiteor muddy-water rivers with headwaters in the Andes (i.e., Solimões, Madeira and Japurá) and by tributaries draining the western lowlands as Purus and Juruá (Lima \& Ribeiro 2011), composing the floodplains popularly known as várzeas (Sioli 1984). This region is characterized by elevated load of sediments and dissolved inorganic solids (Sioli 1984, Goulding et al. 2003). The fish species richness in Lowland Amazonia is directly related to the exceptional diversity of the floodplains (Crampton 2011) and might also be influenced by the tributary effect that enriches the species diversity of Amazon mainstream, especially the white water tributaries from the Western region (Fernandes et al. 2004).

The rio Purus is one of the largest tributaries of the rio Solimões, with an extension of 2,765.65 km (Melo 2012) from its sources in Peru until its confluence on rio Solimões, at Amazonas State. It represents the largest fishing productivity of Amazon basin compared to other major white-water tributaries (Petrere 1978, Batista 1998, 2003), however, the efforts are concentrated in a few species, from which only 12 represent $80 \%$ of the fish landed in the main ports of Amazonas State (Barthem \& Fabre 2003). Despite this potential, few studies were conducted in order to investigate the ichthyofauna of this basin. Most focused on the upper portion of the river, with 48 species recorded in the río Macauhan (tributary of río Yaco) (La Monte 1935), 86 species in Caeté and Macapá rivers (Anjos et al. 2008), and 94 species in rio Acre (Claro-García et al. 2013). The investigations in lower rio Purus registered higher number of species: 180 by Rapp Py-Daniel \& de Deus (2003) in flooded areas, and approximately 110 species in two sandy beaches of Reserva Biológica de Abufari and Reserva de Desenvolvimento Sustentável Piagaçu-Purus (RDS-PP) (Duarte et al. 2010).

The RDS-PP was created in 2003 by the Amazonas State Government, to conciliate usage of natural resources with socioenvironmental sustainability. The region was deeply exploited for terrestrial and aquatic resources during the first half of twentieth century (Vieira et al. 2015). Activities as fishing, hunting, and practice of small-scale agriculture and extractivism are allowed to approximately
60 communities with 4,000 residents (de Deus et al. 2003, IPI 2010). Fishing rules agreement determining management practices and fisheries areas were established in 2008 by local population and signed in agreements. Floodplain lakes were divided in a zoning model into two categories: open access and protected. In open access lakes subsistence and commercial fishing are allowed, while in protected lakes commercial fishing is prohibited (IPI 2010). The zoning model adopted in RDSPP is similar to the model pioneered in RDS-Mamirauá (Queiroz \& Crampton 1999).

The reserve is comprised of both upland terra firme landscapes and flooded forests, the latter representing $45 \%$ of its area, more concentrated on its North region, on the interfluve of Solimões and Purus rivers (de Deus et al. 2003; IPI 2010). The confluence of Purus and Solimões rivers generates a large floodplain area in the lower portion of the basin, with many environments still unexplored, which require huge sampling efforts to improve the fish fauna knowledge and fisheries consequences in natural sources. In this study, we sampled, for the first time, floodplain lakes in RDS-PP, with different management efforts, that represent important resources for commercial fishing in North region. Therefore, the main goals of this study were: (i) register the composition of fish species that occur in the RDS-PP floodplain lakes of different zoning model categories: open access and protected; and (ii) provide the first illustrated inventory of the ichthyofauna from floodplain lakes of lower rio Purus basin.

\section{Material and Methods}

\section{Study area}

The Reserva de Desenvolvimento Sustentável Piagaçu-Purus $\left(4^{\circ} 03^{\prime}-5^{\circ} 25^{\prime} \mathrm{S}\right.$ and $\left.61^{\circ} 40^{\prime}-63^{\circ} 30^{\prime} \mathrm{W}\right)$ comprises 834,245 ha situated along the lower rio Purus basin (Fig. 1), $223 \mathrm{~km}$ upstream from Manaus, capital of Amazonas State (Vieira et al. 2015). Surveys were carried in 20 floodplain lakes of the RDS-PP between October and November 2009, during low water levels on lower rio Purus (Tab. 1). Lakes were chosen according to access availability, and were previously classified by the zoning model as eight open access and 12 protected (Fig. 1).

\section{Data Collection}

Sampling efforts were standardized for all lakes. Fishing gear consisted in a set of stationary gillnets (10 $\mathrm{m}$ length) with mesh sizes 40, 60, 80, 100 and $120 \mathrm{~mm}$ between opposite knots, exposed for 24 hours starting at 6:00 AM, with harvests at fours hours. The exposure time was defined in order to minimize the damage caused by piscivorous fish, dolphins and alligators to gillnet and fish caught. 


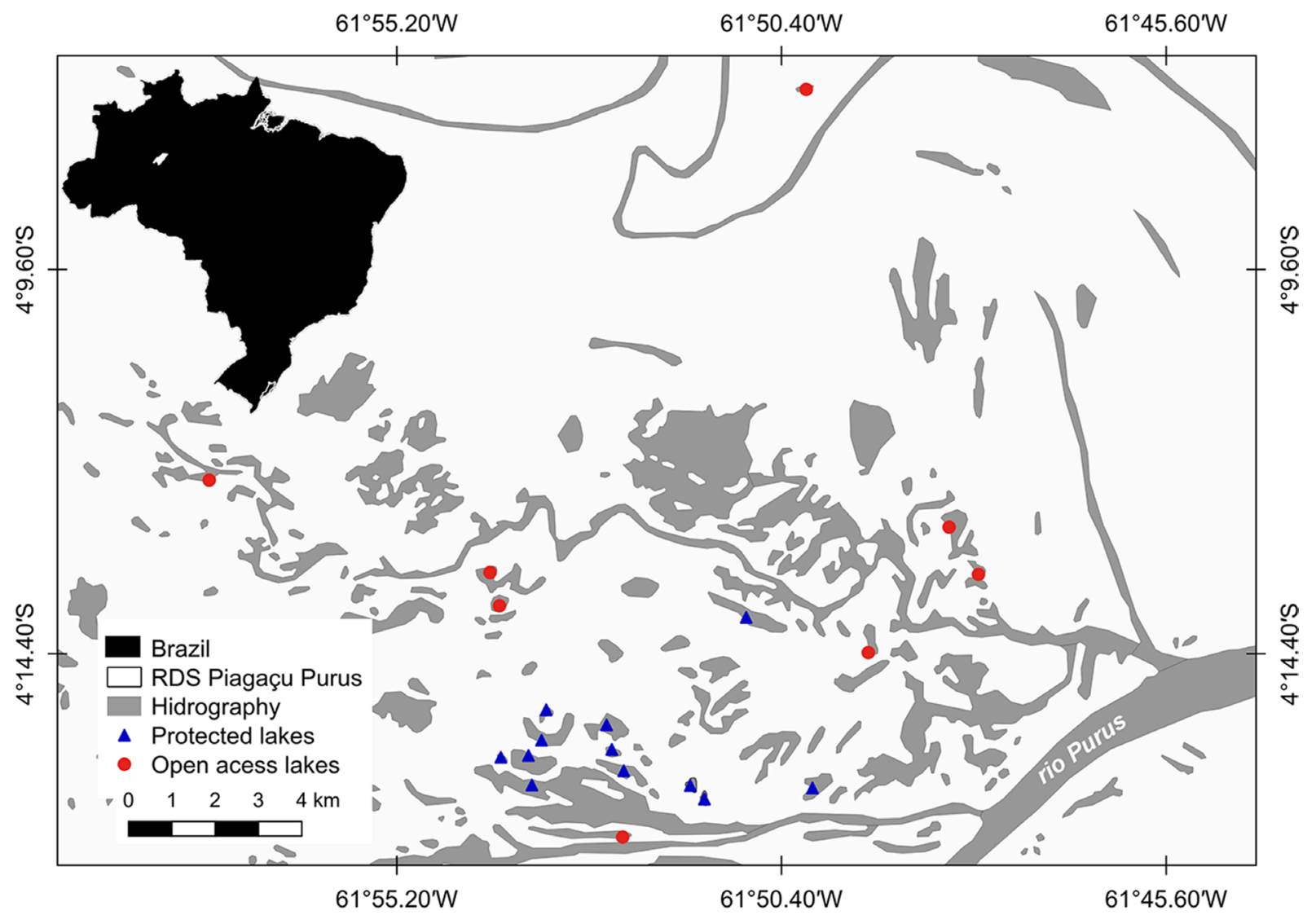

Figure 1. Map of the study area showing the location of the Reserva de Desenvolvimento Sustentável Piagaçu-Purus (RDS-PP) in Amazonas State, and sampled floodplain lakes from rio Purus.

Table 1. Sampled floodplain lakes from rio Purus at Reserva de Desenvolvimento Sustentável Piagaçu-Purus (RDS-PP) in Amazonas State.

\begin{tabular}{|c|c|c|c|}
\hline Site & Name of the lake & Category & Coordinates \\
\hline 1 & Cobra & Open access & $4^{\circ} 13^{\prime} 24.5^{\prime \prime S} / 61^{\circ} 47^{\prime} 56.6^{\prime \prime} \mathrm{W}$ \\
\hline 2 & Pepu Grande & Open access & $4^{\circ} 12^{\prime} 49.1^{\prime \prime S} / 61^{\circ} 48^{\prime} 18.6^{\prime \prime W}$ \\
\hline 4 & Panela & Open access & $4^{\circ} 12^{\prime} 11.5^{\prime \prime} \mathrm{S} / 61^{\circ} 57^{\prime} 30.0^{\prime \prime} \mathrm{W}$ \\
\hline 5 & Macacão & Open access & $4^{\circ} 13^{\prime} 20.2^{\prime \prime S} / 61^{\circ} 53^{\prime} 53.3^{\prime \prime W}$ \\
\hline 8 & Fortuna & Open access & $4^{\circ} 07^{\prime} 22.5^{\prime \prime S} / 61^{\circ} 50^{\prime} 00.8^{\prime \prime} \mathrm{W}$ \\
\hline 9 & Marajá & Protected & $4^{\circ} 13^{\prime} 52.8^{\prime \prime S} / 61^{\circ} 50^{\prime} 48.0^{\prime \prime} \mathrm{W}$ \\
\hline 10 & Cedro & Protected & $4^{\circ} 15^{\prime} 45.9^{\prime \prime} \mathrm{S} / 61^{\circ} 53^{\prime} 56.9^{\prime \prime} \mathrm{W}$ \\
\hline 11 & Caverna & Protected & $4^{\circ} 15^{\prime} 25.0^{\prime \prime} \mathrm{S} / 61^{\circ} 53^{\prime} 33.7^{\prime \prime} \mathrm{W}$ \\
\hline 15 & Redondo 2 & Protected & $4^{\circ} 15^{\prime} 35.6^{\prime \prime} \mathrm{S} / 61^{\circ} 52^{\prime} 31.1^{\prime \prime W}$ \\
\hline 16 & Redondo 3 & Protected & $4^{\circ} 15^{\prime} 28.6^{\prime \prime} \mathrm{S} / 61^{\circ} 52^{\prime} 28.5^{\prime \prime} \mathrm{W}$ \\
\hline 17 & Redondo do Caverna 1 & Protected & $4^{\circ} 15^{\prime} 48.2^{\prime \prime} \mathrm{S} / 61^{\circ} 53^{\prime} 17^{\prime \prime} \mathrm{W}$ \\
\hline 18 & Redondo do Carvena 2 & Protected & $4^{\circ} 15^{\prime} 50.3^{\prime \prime} \mathrm{S} / 61^{\circ} 53^{\prime} 25.4^{\prime \prime} \mathrm{W}$ \\
\hline 19 & Henrique & Protected & $4^{\circ} 16^{\prime} 05.4^{\prime \prime S} / 61^{\circ} 51^{\prime} 29.3^{\prime \prime W}$ \\
\hline 20 & Mureruzinho & Protected & $4^{\circ} 16^{\prime} 12.0^{\prime \prime} \mathrm{S} / 61^{\circ} 51^{\prime} 23.5^{\prime \prime} \mathrm{W}$ \\
\hline
\end{tabular}


In field, fish specimens were anesthetized in benzocaine hydrochloride, and fixed in $10 \%$ formalin and weighted to define the individual biomass. Total biomass of each species was represented by the sum of the weight of all specimens collected. Posteriorly, specimens were transferred to $70 \%$ ethanol in the laboratory and deposited in the Coleção de Peixes do Instituto Nacional de Pesquisas da Amazônia (INPA, Manaus, Amazonas State).

\section{Fishfauna}

The classification of families and subfamilies were presented in alphabetical order due to the many changes in the current classifications, and the lack of congruence or resolution regarding the relationships between them. The nomenclatural arrangement and classification of groupings in levels higher than family and family names followed Betancur-R. et al. (2017). Sub-families of Characidae followed Mirande (2018), and of Loricariidae followed Armbruster (2004), with the exception of Rhinelepinae, which is according to Lujan et al. (2015). Identification follows Menezes \& Géry (1983), Kullander \& Ferreira (2006), Santos et al. (2006), Bristki \& Birindelli (2008), Zarske \& Géry (2008), Queiroz et al. (2013), Littmann et al. (2015), Andrade et al. (2016), Ferraris et al. (2017), Ramirez et al. (2017), Ribeiro et al. (2017), and Mateussi et al. (2018).

\section{Results}

A total of 2,299 individuals were collected, distributed in seven orders, 25 families and 74 species (Tab. 2, Figs. 2-4). Characiformes was the most representative order in number of species and families (44 and 14 , respectively), followed by Siluriformes with 20 species and six families (Fig. 5), Cichliformes, with only one family but five species, and Gymnotiformes (two species in two families). Clupeiformes, Osteoglossiformes and Perciformes were less representative, with only one species each.

Characiformes and Siluriformes presented major number of species. The families with higher species richness were Serrasalmidae (12 species), Curimatidae and Pimelodidae (7 species), and Loricariidae (5 species) (Fig. 6). Highest abundances were also observed for Characiformes and Siluriformes with 1,888 and 279 individuals respectively.

Most abundant and frequent species were Pygocentrus nattereri (piranha caju) with 880 individuals collected in $90 \%$ of sampled lakes, followed by Triportheus angulatus (sardinha-papuda) (276 individuals and $80 \%$ of lakes), Serrasalmus sp. $2 \mathrm{n}=58$ (piranha preta) (157 individuals in $80 \%$ of lakes), Pterygoplichthys gibbiceps (bodó) (100 individuals in 65\% of lakes), and Osteoglossum bicirrhosum (aruanã) with 76 individuals captured in $65 \%$ of lakes. Species represented by only one individual represented $28.5 \%$ of the total catch. With exception of Serrasalmus maculatus, with scarce number of individuals (59) but collected in $65 \%$ of lakes, the other species were found in less than $45 \%$ of the lakes.

Four species presented high biomass levels, representing $72.7 \%$ of total $359.5 \mathrm{~kg}$ collected, P. nattereri (32.4\%), O. bicirrhosum (20.8\%), Colossoma macropomum (tambaqui) (11.8\%), and $P$. gr. gibbiceps (7.7\%). Despite the great contribution of C. macropomum biomass it occurred in only $20 \%$ of the sampled sites (all protected lakes), differing from the others that occurred in at least $60 \%$ of the lakes.
Protected lakes presented higher species richness (62 species) compared to open access lakes with 48 species collected (Table 3). Similarly, protected lakes possessed 26 species occurring exclusively in this category (e.g., Brycon spp., Colossoma macropomum, Curimata inornata, Hypophthalmus spp., and Pseudoplatystoma spp.), while in open access lakes this number was reduced to 12 species (e.g. Loricariichthys acutus, Mylossoma aureum, and Semaprochilodus taeniurus). However, beyond the dominance of Characiformes and Siluriformes in both type of lakes, Cichliformes did not occur in protected lakes, while in open access lakes five species were collected, including commercially important as (Astronotus ocellatus and Cichla monoculus). Open access lakes presented higher abundance of Characiformes than protected lakes, mainly due to the participation of P. nattereri (Tab. 3).

Species accumulation curve is concerned with accumulation rates of new species over the sampled area and depends on species identity. Considering all lakes sampled, the species accumulation curve did not completely reach the asymptote (Fig. 7). Species richness expectation obtained by nonparametric estimators indicated that was collected $72 \%$ of the species expected to lakes by Jacknife estimate $1($ Jack1 = 107.4), $60 \%$ by Jacknife estimate $2($ Jack $2=12,5), 57.5 \%$ by Chao estimate $($ Chao $=133.89)$ and $85.8 \%$ according to the Bootstrap estimator.

\section{Discussion}

The ichthyofauna of floodplain lakes of RDS Piagaçu-Purus on lower rio Purus, as remaining freshwater regions of the world, is composed mostly by Ostariophysi, representing $88.2 \%$ of total richness. Characiformes presented higher families representativeness from which Serrasalmidae and Curimatidae composed $25 \%$ of all diversity surveyed by us. The predominance of these two families is different from previous results registered for lower rio Purus. From the 90 species inventoried using gillnets by Rapp Py-Daniel \& de Deus (2003), mostly belong to Anostomidae (10), Serrasalmidae (8) and Hemiodontidae (6), whereas only Hemiodus sp. "rabo de fogo" and five species of anostomids were captured in the present study. The former study was developed during high water levels (June) and fish were sampled in different types of environments (lakes, paranás, igarapés and river channel), while the present investigation was performed in low water levels (October and November) strictly in lakes.

The lower rio Purus, next to its confluence with rio Solimões generates a large floodplain. Flooded areas are known by suffer seasonally dramatic changes in landscapes, modeled by the flood pulse (Junk et al. 1989). During wet period flooded forest consists an important feeding source of fruits and seeds, providing a wider diversity of habitat options, decreasing the density of possible predators (Winemiller \& Jepsen 1998, Lowe-McConnell 1999). In low water ichthyofauna migrates to available habitats, including main river channel and permanent lakes, increasing predators occurrence in consequence of the reduction of suitable occupancy areas (Goulding 1980). These environmental differences are essential to the maintenance of life cycle of many fish species and biological interactions (Duarte et al. 2010). Despite the efficiency and selectivity of the use of a unique sampling effort (gillnet) we reached a representative number of species (74) and complemented available information of ichthyofauna from lower rio Purus, surveying for 
Table 2. List of fish species captured in floodplain lakes of Reserva de Desenvolvimento Sustentável Piagaçu-Purus (RDS-PP), lower rio Purus, in 2009 drought. The references for the classification used are listed in the Material and Methods section. (Locality: 1. Cobra; 2. Pepu grande; 3. Adão; 4. Panela; 5. Macacão; 6. Macaco; 7. Igarapé Açu; 8. Fortuna; 9. Marajá;10. Cedro; 11. Caverna; 12. Caverninha;13. Tucuxi; 14. Redondo 1; 15. Redondo 2; 16. Redondo 3; 17. Redondo do caverna 1; 18. Redondo do caverna 2; 19. Henrique; 20. Mureruzinho. Bold numbers are for Protected lakes).

\begin{tabular}{llc}
\hline Classification & Locality & Voucher INPA
\end{tabular}

\section{TELEOSTEI}

OSTEOGLOSSOCEPHALAI

\section{OSTEOGLOSSIFORMES}

\section{Osteoglossidae}

Osteoglossum bicirrhosum (Cuvier, 1829)

\section{CLUPEIFORMES}

\section{Pristigasteridae}

Pellona flavipinnis (Valenciennes, 1837)

\section{CHARACIFORMES}

\section{Acestrorhynchidae}

Acestrorhynchus microlepis (Jardine, 1841)

Acestrorhynchus cf. pantaneiro Menezes, 1992

1

$1,2,4,6,7,9,17,18,20$

$1,4,5,8, \mathbf{1 2}, \mathbf{1 8 , 1 9}$

6,10

$2,3,12$

$3,4,5,6,7,9,10,11,12,14,15,19,20$

$1,4,5,9,13,14,15,16,19$

13

13

$1,2,4,5,8, \mathbf{9 , 1 3 , 1 9 , 2 0}$

$1,3,4, \mathbf{1 3}, \mathbf{1 4}, \mathbf{1 7}$

13

17

13

\section{Curimatidae}

Curimata inornata Vari, 1989

Curimatella alburna (Müller \& Troschel, 1844)

Potamorhina altamazonica (Cope, 1878)

Potamorhina pristigaster (Steindachner, 1876)

Psectrogaster amazonica Eigenmann \& Eigenmann, 1889

Psectrogaster rutiloides (Kner, 1858)

Steindachnerina bimaculata (Steindachner, 1876)

\section{Cynodontidae}

Cynodon gibbus (Spix \& Agassiz, 1829)

Rhaphiodon vulpinus Spix \& Agassiz, 1829
$1,7,17,18,19$

$1,2,7,9,16,17,18,19,20$

4

$1,2,7, \mathbf{1 7}, \mathbf{1 8 , 1 9}$

$1,2, \mathbf{1 6}$

$1,2,4,8, \mathbf{1 0}, \mathbf{1 6}, \mathbf{1 7}, \mathbf{1 9}$

$1,2,16$

$1,3,4,7, \mathbf{1 1}, \mathbf{1 2 , 1 5 , 1 7 , 1 8}$
36573

36718

42420

42394

17152

23749, 36738

36714, 48861

36734, 36737

36724

41882

36599,36720

17122,23628

36665

17257, 17235

23638,36707

36708,36715

36746

23617, 36730

36594, 36736

36558,36740

36600, 36626

23746

18551, 32043 
Continuation Table 2.

\begin{tabular}{|c|c|c|}
\hline Classification & Locality & Voucher INPA \\
\hline \multicolumn{3}{|l|}{ Erythrinidae } \\
\hline Hoplias malabaricus (Bloch, 1794) & $1,2,3,6, \mathbf{1 0}, \mathbf{1 2 , 1 5 , 1 6}$ & 33740,48374 \\
\hline Hemiodus sp. "rabo de fogo" & 5,13 & 36706 \\
\hline \multicolumn{3}{|l|}{ Iguanodectidae } \\
\hline Prochilodus nigricans Spix \& Agassiz, 1829 & $1,3,6, \mathbf{1 1}$ & 41661 \\
\hline Semaprochilodus insignis (Jardine, 1841) & $1,4,5,8, \mathbf{1 0}, \mathbf{1 3}, \mathbf{1 7 , 2 0}$ & 41691 \\
\hline Semaprochilodus taeniurus (Valenciennes, 1821) & 18 & 42456 \\
\hline \multicolumn{3}{|l|}{ Serrasalmidae } \\
\hline Myloplus torquatus (Kner, 1858) & 9 & 36702 \\
\hline Mylossoma albiscopum (Cope, 1872) & $1,2,3,5,6, \mathbf{1 1}, \mathbf{1 3}$ & 36683,36686 \\
\hline Mylossoma aureum (Spix \& Agassiz, 1829) & 4 & 16776,41655 \\
\hline Pristobrycon striolatus (Steindachner, 1908) & 13 & 36703,41917 \\
\hline Pygocentrus nattereri Kner, 1858 & $1,2,3,4,5,6,7,8, \mathbf{9 , 1 0}, \mathbf{1 1}, \mathbf{1 2}, \mathbf{1 3}, \mathbf{1 4}, \mathbf{1 5}, \mathbf{1 6}, \mathbf{1 7}, \mathbf{1 8}$ & 41663,41689 \\
\hline Serrasalmus elongatus Kner, 1858 & $1,2,4,5,6,7,8, \mathbf{9 , 1 0 , 1 3 , 1 7 , 1 8}$ & 36672,36705 \\
\hline Serrasalmus maculatus Kner, 1858 & $1,2,3,4,5,7,8, \mathbf{9 , 1 1 , 1 2 , 1 5 , 1 8 , 1 9}$ & 36698,36699 \\
\hline Serrasalmus rhombeus (Linnaeus, 1766) & 13 & 36704,36693 \\
\hline Serrasalmus sp. "2n=58" & $1,2,3,4,5,7,8, \mathbf{9 , 1 0 , 1 1 , 1 3 , 1 5 , 1 6 , 1 7 , 1 8 , 1 9}$ & 36670,36673 \\
\hline \multicolumn{3}{|l|}{ Rhamphichthyidae } \\
\hline Rhamphichthys pantherinus Castelnau, 1855 & 3,17 & 27614,42430 \\
\hline \multicolumn{3}{|l|}{ Sternopygidae } \\
\hline Eigenmannia macrops (Boulenger, 1897) & 14 & 36717 \\
\hline \multicolumn{3}{|l|}{ SILURIFORMES } \\
\hline \multicolumn{3}{|l|}{ Auchenipteridae } \\
\hline Ageneiosus inermis (Linnaeus, 1766) & $11,15,16$ & 36728,41700 \\
\hline Trachelyopterus galeatus (Linnaeus, 1766) & $12,14,15$ & 36661,41790 \\
\hline Trachychorystis porosus Eigenmann \& Eigenmann, 1888 & 2,12 & 36732,36735 \\
\hline \multicolumn{3}{|l|}{ Doradidae } \\
\hline Anadoras grypus (Cope, 1872) & $10,12,14,15$ & 36733 \\
\hline Oxydoras niger (Valenciennes, 1821) & $2,3,5,11$ & 36731 \\
\hline \multicolumn{3}{|l|}{ Callichthyidae } \\
\hline Dianema urostriatum (Miranda Ribeiro, 1912) & 20 & 36722 \\
\hline Hoplosternum littorale (Hancock, 1828) & $1,3,4,5,6, \mathbf{1 0}, 12$ & 36710 \\
\hline
\end{tabular}


Continuation Table 2.

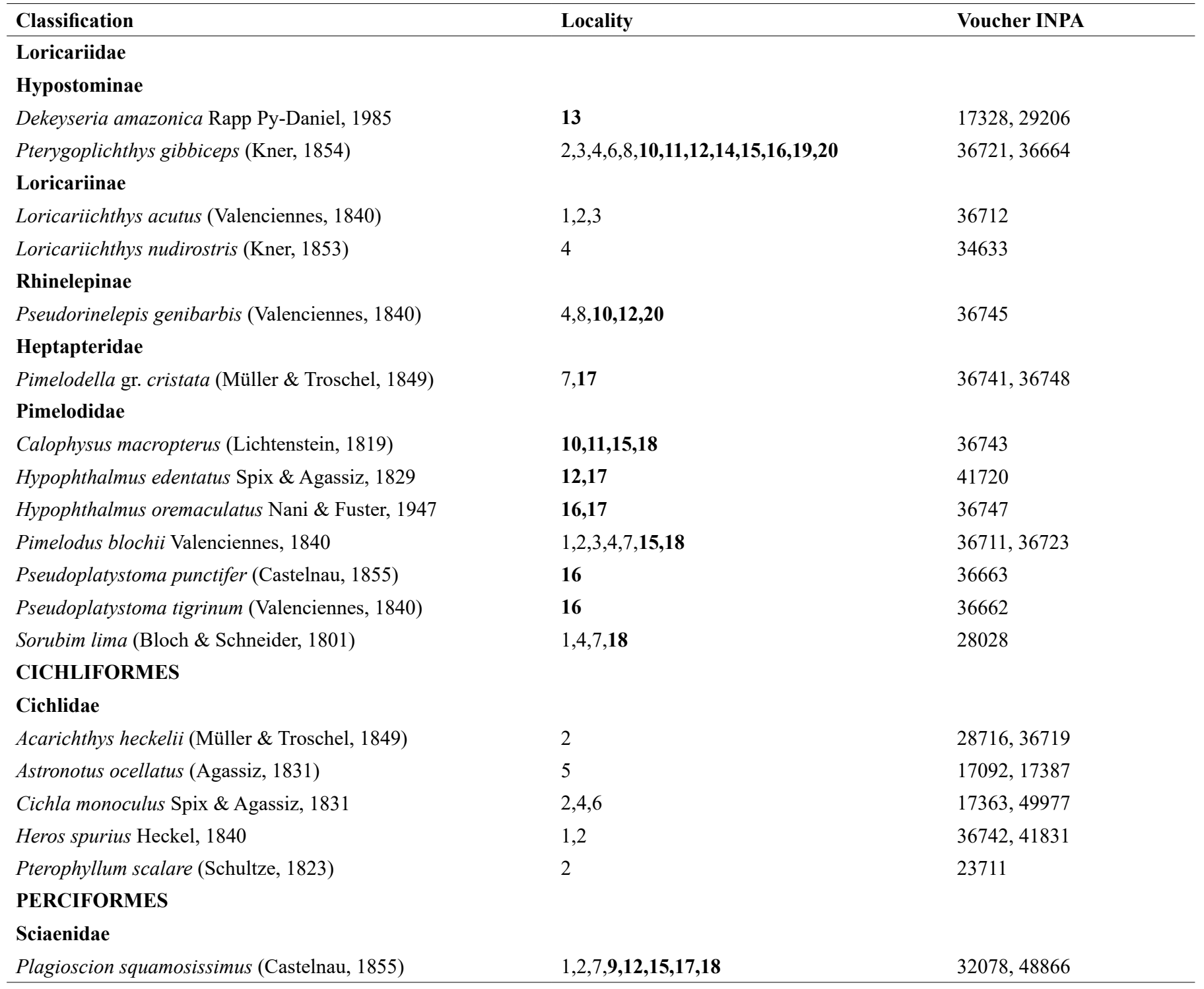

the first time flooded lakes from RDS-PP during the dry season. As expected, composition of ichthyofauna changed significantly, with 44 new species recorded by us for this region.

The most abundant and frequent species, occurring in more than $60 \%$ of sampled lakes, including open access and protected, were Pygocentrus nattereri, Triportheus angulatus, Serrasalmus sp. $2 \mathrm{n}=58$, Pterygoplichthys gibbiceps, and Osteoglossum bicirrhosum, all consumed by local population of RDS-PP. Similarly, in floodplain lakes of another reserve (RDS Mamiraua) in Solimões river, piranhas (Serrasalmus spp. and P. nattereri) and aruanã (Osteoglossum bicirrhosum) were the main collected species (Silvano et al. 2009). Osteoglossum bicirrhosum is a relevant artisanal fisheries resource in the entire Amazon (Lowry et al. 2005), and is also used as ornamental in aquarium trades (Santos et al. 2006). Apart from its intense exploitation, the aruanã was the third most abundant with the second highest biomass registered by us. This success can be attributed to the generalist feeding behavior, hunting along lake borders and flooded forests, allied to capacity of exploiting allochthonous food items during the high-water season (Saint-Paul et al. 2000, Lowry et al. 2005, Castillo et al. 2012), by leaping from the water to seek allochthonous prey, including terrestrial invertebrates (Aragão 1984, Goulding 1980) and small vertebrates (Verba et al. 2018).

In the comparison between the two lakes categories, open access presented less number of species (48vs. 62 in protected). Nevertheless, from the 12 exclusively captured in these lakes, several possess elevated importance for artisanal and commercial fisheries, as Pellona flavipinnis, Semaprochilodus taeniurus, Mylossoma aureum, and the cichlids Astronotus ocellatus and Cichla monoculus, indicating the efficacy of choice of these lakes for fish exploration. On the other hand, the exclusive capture of Colossoma macropomum in protected lakes in RDS Piagaçu-Purus, indicates the efficiency of fishing management model adopted, that had already registered a major probability of capture and higher abundance of this species in protected lakes of RDS Mamirauá (Silvano et al. 2009). 


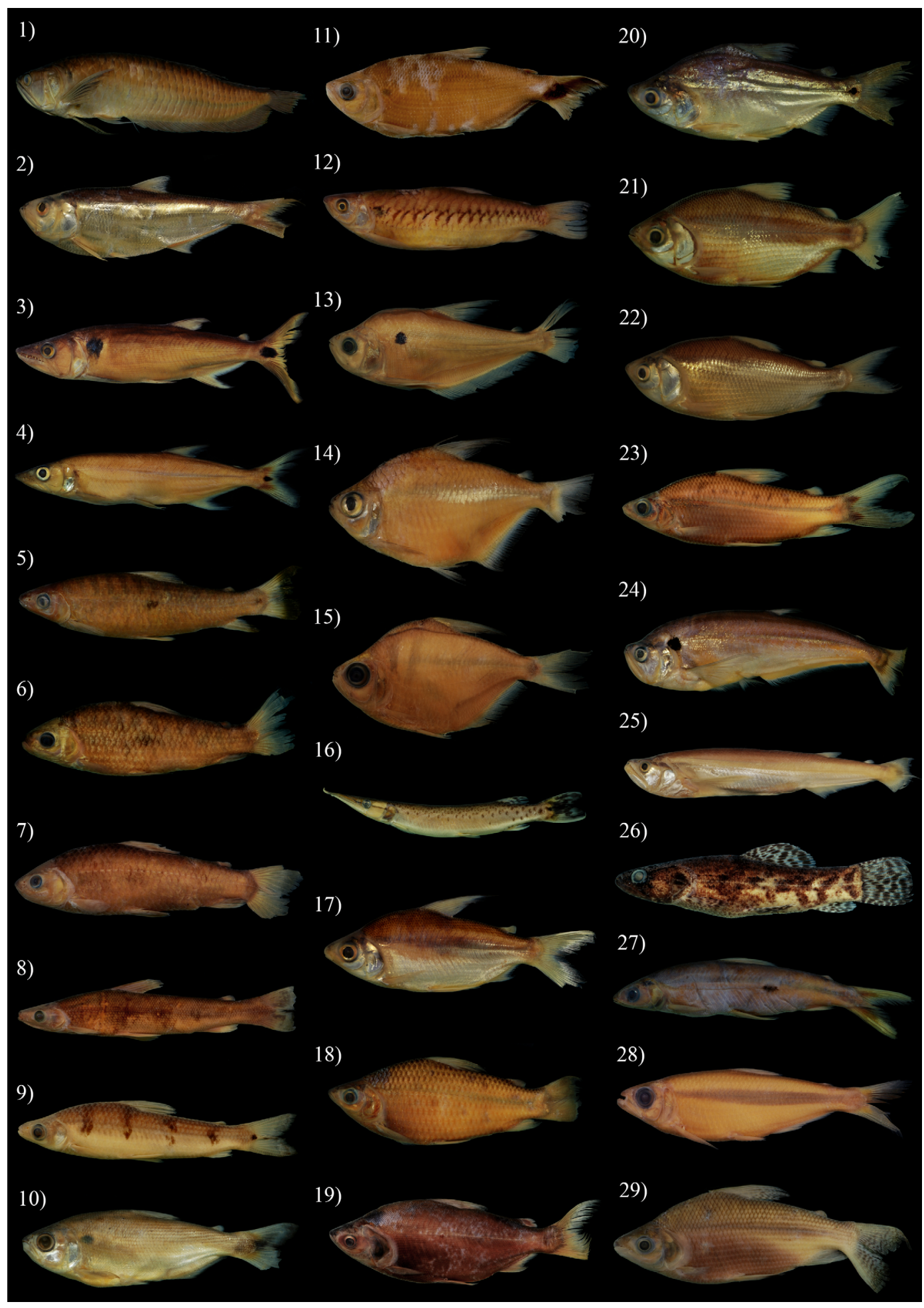

Figure 2. Fish species from floodplain lakes of Reserva de Desenvolvimento Sustentável Piagaçu-Purus (RDS-PP), lower rio Purus, Amazonas State, Brazil. 1) Osteoglossum bicirrhosum INPA 17228, 278.8 mm SL; 2) Pellona flavipinnis INPA 34030, $231.0 \mathrm{~mm}$ SL; 3) Acestrorhynchus cf. pantaneiro INPA $23749,212.8$ mm SL; 4) Acestrorhynchus microlepis INPA 17152, $133.0 \mathrm{~mm}$ SL; 5) Leporinus friderici INPA 48861, $186.7 \mathrm{~mm}$ SL; 6) Leporinus parae INPA $36734,132.5 \mathrm{~mm}$ SL; 7) Megaleporinus trifasciatus INPA 36724, $178.5 \mathrm{~mm}$ SL; 8) Rhytiodus microlepis INPA 41882, $166.8 \mathrm{~mm}$ SL; 9) Schizodon fasciatus INPA $36599,131.4$ mm SL; 10) Brycon amazonicus INPA 17122, $135.8 \mathrm{~mm}$ SL; 11) Brycon melanopterus INPA 36665, $163.7 \mathrm{~mm}$ SL; 12) Chalceus erythrurus INPA 17235, $174.2 \mathrm{~mm}$ SL; 13) Roeboides myersii INPA 36573, $108.1 \mathrm{~mm} \mathrm{SL}$; 14) Tetragonopterus argenteus INPA 36718, $64.2 \mathrm{~mm}$ SL; 15) Tetragonopterus chalceus INPA 42420, 91.1 mm SL; 16) Boulengerella maculata INPA 42394, 192.9 mm SL; 17) Curimata inornata INPA 23638, $130.5 \mathrm{~mm}$ SL; 18) Curimatella alburna INPA $36708,148.8$ mm SL; 19) Potamorhina altamazonica INPA 36746, $172.3 \mathrm{~mm}$ SL; 20) Potamorhina pristigaster INPA 36730, 172.2 mm SL; 21) Psectrogaster amazonica INPA 36594, $114.2 \mathrm{~mm} \mathrm{SL}$; 22) Psectrogaster rutiloides INPA 36558, $126.3 \mathrm{~mm}$ SL; 23) Steindachnerina bimaculata INPA 36626, 93.0 mm SL; 24) Cynodon gibbus INPA 23746, $207.7 \mathrm{~mm}$ SL; 25) Rhaphiodon vulpinus INPA 32043, $220.0 \mathrm{~mm}$ SL; 26) Hoplias malabaricus INPA 48374, 100.8 mm SL; 27) Hemiodus sp. "rabo de fogo" INPA 36706, 151.0 mm SL; 28) Bryconops melanurus INPA 36709, 94.4 mm SL; 29) Prochilodus nigricans INPA $41661,155.6$ mm SL. 


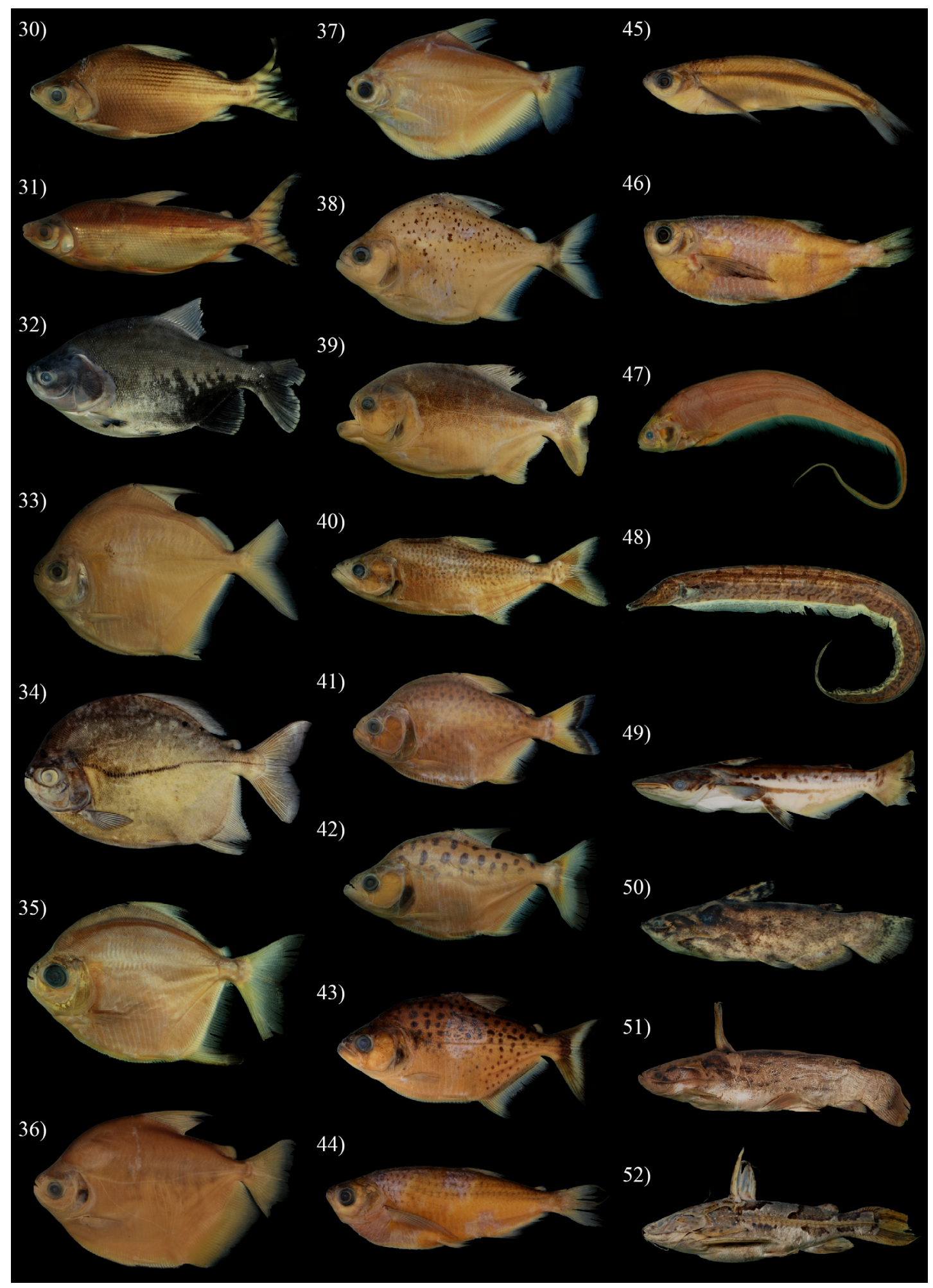

Figure 3. Fish species from floodplain lakes of Reserva de Desenvolvimento Sustentável Piagaçu-Purus (RDS-PP), lower rio Purus, Amazonas State, Brazil. 30) Semaprochilodus insignis INPA 41691, 128.4 mm SL; 31) Semaprochilodus taeniurus INPA 42456, 222.5 mm SL; 32) Colossoma macropomum INPA 58771, 357.6 mm SL; 33) Metynnis longipinnis INPA 39502, 98.9 mm SL; 34) Myloplus aff. asterias INPA 58772, $189.3 \mathrm{~mm}$ SL; 35) Myloplus torquatus INPA $36702,78.8$ mm SL; 36) Mylossoma aureum INPA 41655, $129.6 \mathrm{~mm}$ SL; 37) Mylossoma albiscopum INPA 36686, $124.8 \mathrm{~mm}$ SL; 38) Pristobrycon striolatus INPA 41917, 102.5 mm SL; 39) Pygocentrus nattereri INPA 41689, 168.9 mm SL; 40) Serrasalmus elongatus INPA 36705, 134.4 mm SL; 41) Serrasalmus maculatus INPA $36699,116.8$ mm SL; 42) Serrasalmus rhombeus INPA 36693, $109.0 \mathrm{~mm}$ SL; 43) Serrasalmus sp. "2n=58" INPA 36670, $104.0 \mathrm{~mm}$ SL; 44) Triportheus angulatus INPA 36713, $126.9 \mathrm{~mm}$ SL; 45) Triportheus auritus INPA 36666, $94.4 \mathrm{~mm}$ SL; 46) Triportheus rotundatus INPA 36744, $94.8 \mathrm{~mm}$ SL; 47) Eigenmannia macrops INPA 36717 , $183.1 \mathrm{~mm}$ SL; 48) Rhamphichthys pantherinus INPA 27614, $573.9 \mathrm{~mm}$ SL; 49) Ageneiosus inermis INPA 41700, 126.9 mm SL; 50) Trachelyopterus galeatus INPA 41790, $80.4 \mathrm{~mm}$ SL; 51) Trachychorystis porosus INPA 36732, $102.0 \mathrm{~mm}$ SL; 52) Anadoras grypus INPA 36733, $136.1 \mathrm{~mm}$ SL. 


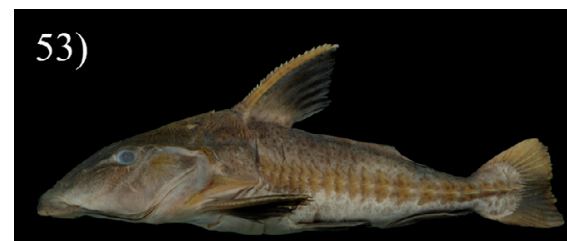

\section{4)}

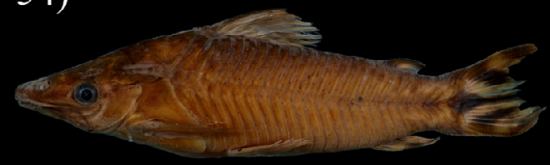

55)
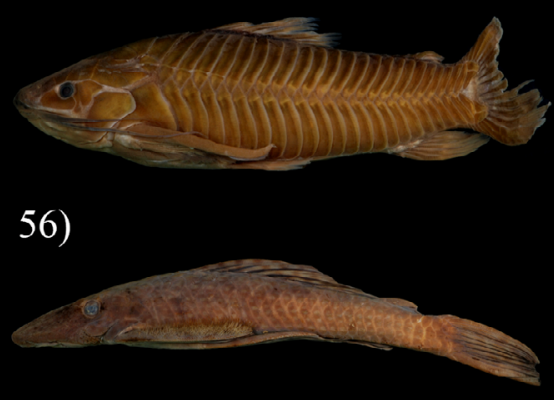

57)

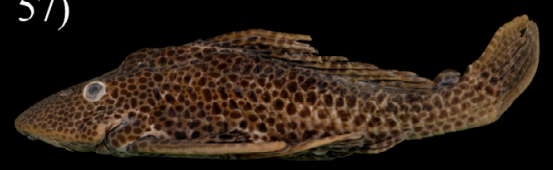

58)

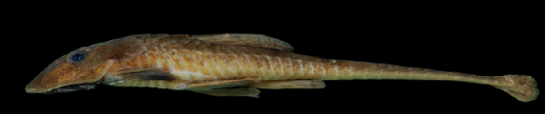

59)
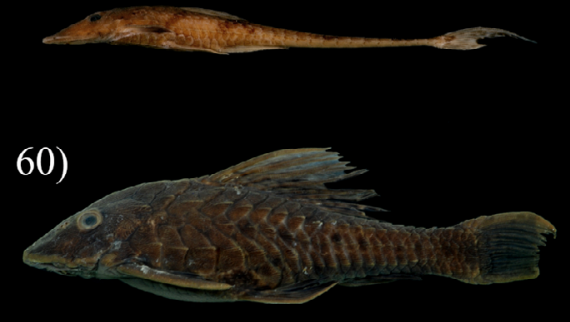

61)

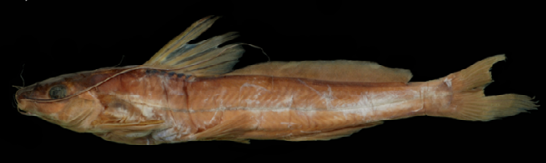

62)

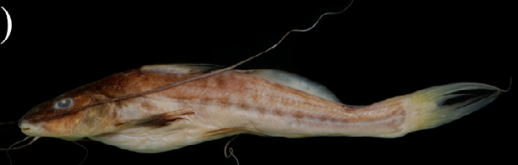

63)

64)
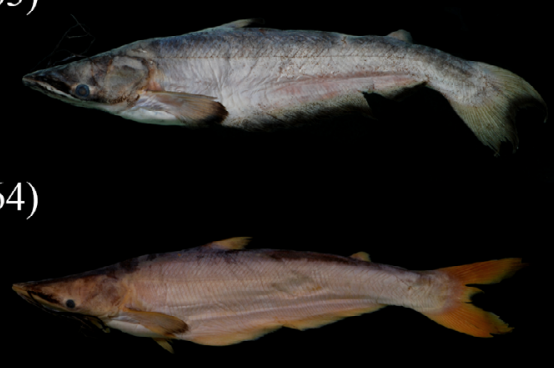

65)

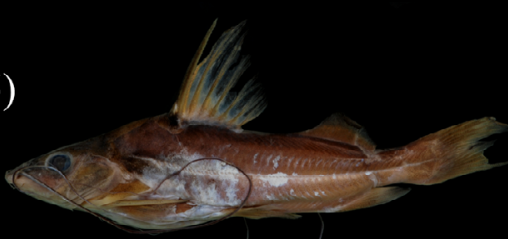

66)

67)
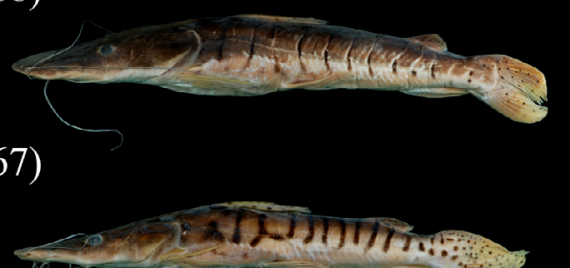

68)

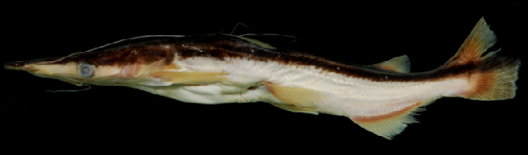

69)

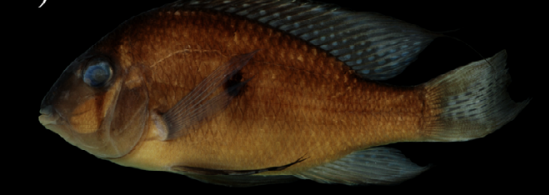

70)

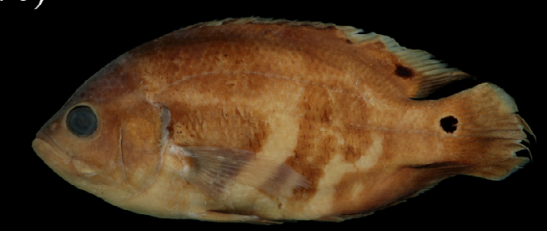

71)

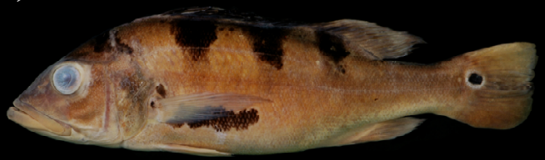

72)

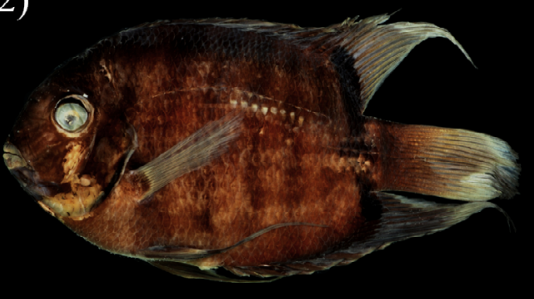

73)

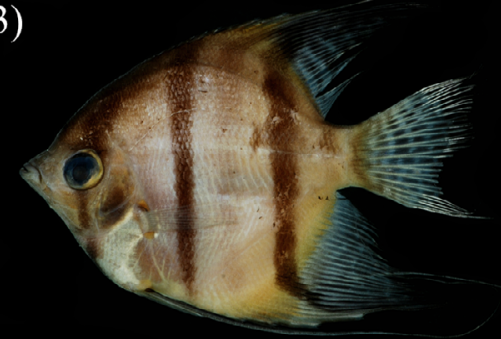

74)

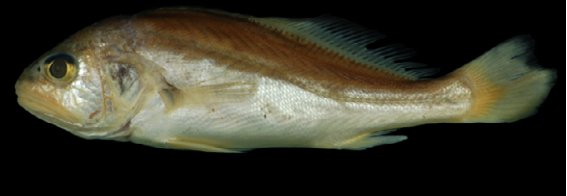

Figure 4. Fish species from floodplain lakes of Reserva de Desenvolvimento Sustentável Piagaçu-Purus (RDS-PP), lower rio Purus, Amazonas State, Brazil. 53) Oxydoras niger INPA 36731, $163.0 \mathrm{~mm}$ SL; 54) Dianema urostriatum INPA 36722, $99.6 \mathrm{~mm}$ SL; 55) Hoplosternum littorale INPA $36710,140.9$ mm SL; 56) Dekeyseria amazonica INPA 29206, 173.9 mm SL; 57) Pterygoplichthys gibbiceps INPA 36664, $251.2 \mathrm{~mm}$ SL; 58) Loricariichthys acutus INPA 36721, 208.1 mm SL; 59) Loricariichthys nudirostris INPA 34633, $95.9 \mathrm{~mm}$ SL; 60) Pseudorinelepis genibarbis INPA 36745, $140.3 \mathrm{~mm}$ SL; 61) Pimelodella gr. cristata INPA 36741 , $120.1 \mathrm{~mm}$ SL; 62) Calophysus macropterus INPA 36743, $113.6 \mathrm{~mm} \mathrm{SL}$; 63) Hypophthalmus oremaculatus INPA 36747, 185.2 mm SL; 64) Hypophthalmus edentatus INPA 41720, $198.7 \mathrm{~mm}$ SL; 65) Pimelodus blochii INPA 36711, 120.6 mm SL; 66) Pseudoplatystoma punctifer INPA 36662, 208.2 mm SL; 67) Pseudoplatystoma tigrinum INPA 36663, $275.5 \mathrm{~mm}$ SL; 68) Sorubim lima INPA 28208, $215.7 \mathrm{~mm}$ SL; 69) Acarichthys heckelii INPA 28716, 101.4 mm SL; 70) Astronotus ocellatus INPA 17387, 170.4 mm SL; 71) Cichla monoculus INPA 49977, $240.2 \mathrm{~mm}$ SL; 72) Heros spurius INPA 41831, 123.4 mm SL; 73) Pterophyllum scalare INPA 23711, $80.3 \mathrm{~mm}$ SL; 74) Plagioscion squamosissimus INPA 32078, $149.6 \mathrm{~mm}$ SL. 


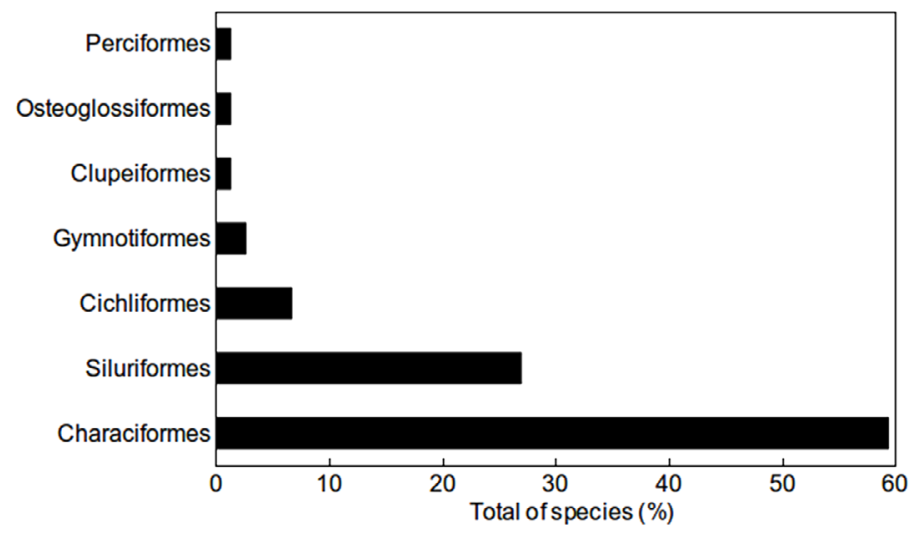

Figure 5. Percentages of the total number of collected species of each order in floodplain lakes from rio Purus, Amazonas State, Brazil.

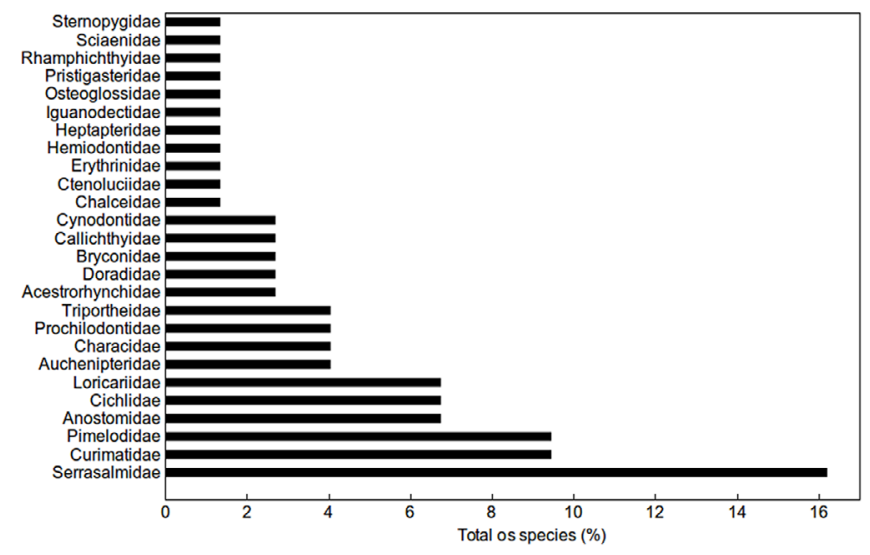

Figure 6. Percentages of the total number of collected species of each family in floodplain lakes from rio Purus, Amazonas State, Brazil.

Table 3. Participation of Teleostei orders in total abundance and species richness observed in protected, open access lakes and shared by protected and open access lakes (overlap) of the lower rio Purus.

\begin{tabular}{|c|c|c|c|c|c|c|}
\hline \multirow[t]{2}{*}{ Orders } & \multicolumn{2}{|c|}{ Protected } & \multicolumn{2}{|c|}{ Open access } & \multicolumn{2}{|c|}{ Protected + Open access } \\
\hline & Species Richness & Abundance & Species Richness & Abundance & Species Richness & Abundance \\
\hline Characiformes & 15 & 69 & 5 & 7 & 24 & 1816 \\
\hline Cichliformes & 0 & 0 & 5 & 9 & 0 & 0 \\
\hline Perciformes & 0 & 0 & 0 & 0 & 1 & 12 \\
\hline Gymnotiformes & 1 & 1 & 0 & 0 & 1 & 3 \\
\hline Total & 26 & 149 & 12 & 22 & 36 & 2128 \\
\hline
\end{tabular}

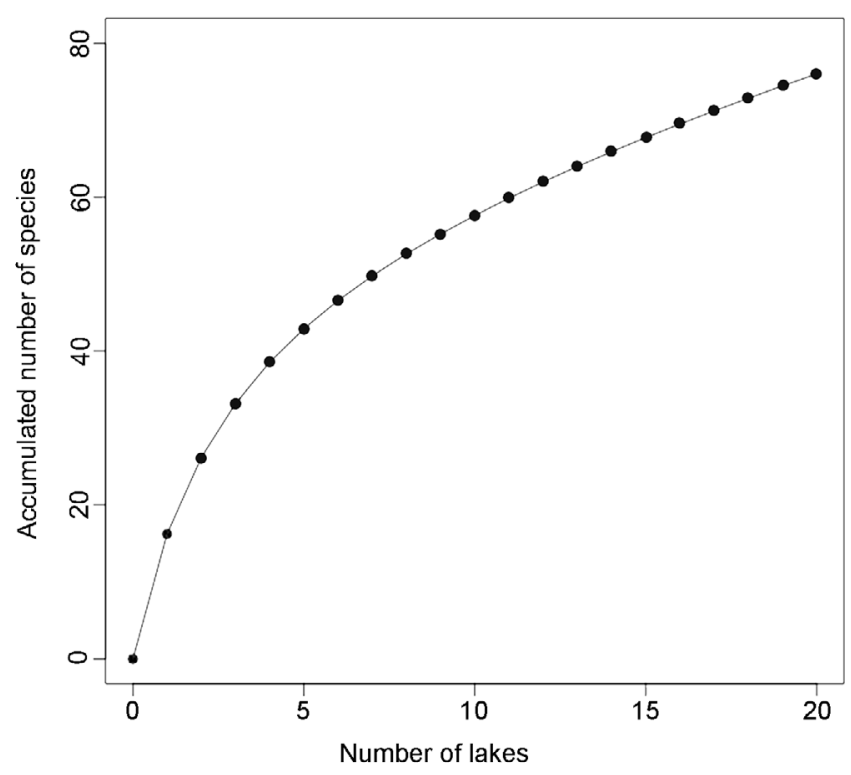

Figure 7. Species accumulation curve of ichtyofauna from floodplain lakes of Reserva de Desenvolvimento Sustentável Piagaçu-Purus (RDS-PP), considering the total number of sample units.
However, this can be a consequence of the overexploitation of $C$. macropomum in open access lakes due to its relevance as feed source of protein for entire Amazon population, but not necessarily mean that such management actions have been ineffective. In marine systems, for example, the main goal of major management is to improve fisheries, allowing some fish landings in managed areas (common-based management), without affecting fish species diversity and ecological integrity (Mcclanahan et al. 1997). Though, the model of integral protection of the lakes adopted in RDS-PP focuses in whole habitat protection, preserving ecological patterns and complexity, and seems to be the factor supporting the ecological stability, beyond providing the local population the most appreciated species for feed consumption.

RDS Piagaçu-Purus provides legal context for monitoring wildlife along with the local population, gathering data and developing strategies for sustainable use. Additionally, it forms a mosaic of protected areas ruled by several different regimes, with two indigenous reserves (Terra Idígena Lago Ayapuá and Itixi Mitari), Reserva Biológica Abufari (REBIO) and Parque Nacional Nascentes do Lago Jari (PARNA), consisting an important region for conservation of ichthyofauna, especially considering fishing productivity of rio Purus. However, recent models of future deforestation in Amazonia predict an increase in the 
loss of vegetation cover for the RDS-PP, related to the reactivation of the road BR-319 (Manaus - Porto Velho), which percuss the interfluve between Madeira and Purus rivers (Soares-Filho et al. 2006, Fearnside et al. 2009, Vieira et al. 2015).

Considering all registers published for the rio Purus basin (i.e. La Monte 1935, Rapp Py-Daniel \& de Deus 2003, Fernandes et al. 2004, Anjos et al. 2008, Duarte et al. 2010; Claro-García et al. 2013, and the present) 360 currently valid species compose the ichthyofauna of this river basin. Still, we strongly believe that this number is underestimated, with much of the basin still unexplored or only sparsely sampled. Our surveys beyond assessing and illustrating for the first time the ichthyofauna composition of floodplain lakes of RDS Piagaçu-Purus, revealed the occurrence of at least three new species for science in rio Purus, Hemiodus sp. "rabo de fogo", Myloplus aff. asterias (under description by RPO et al.), and Serrasalmus sp. $2 \mathrm{n}=58$. Principally, our results indicate the potential efficiency of zoning systems of open access and protected lakes established by local population and ruled by RDS-PP for fisheries management. Therefore, we strongly suggest its maintenance for conservation of ichthyofauna of floodplain lakes of lower rio Purus.

\section{Acknowledgments}

We are grateful to local fisherman (Zé Chico, Mário do Caua, and Irailton) for field support. Thank to Lúcia H. Rapp Py-Daniel and Renildo R. de Oliveira (INPA) for curatorial assistance and identification of Loricariidae species. We are in debt to Jansen Zuanon (INPA) for helping on identification of many species of Characiformes, Michel Jégu (MNHN) for Serrasalmidae assistance, Marcelo Sales Rocha (UEA) for identification of Heptapteridae and Pimelodidae, and Leandro Sousa (UFOPA) for identification of Anadoras grypus. This results were part of the subject of BFM master dissertation. BFM was supported by a M.Sc. scholarship from CNPq (Conselho Nacional de Desenvolvimento em Pesquisas). RPO is funded by Coordenação de Aperfeiçoamento de Pessoal de Nível Superior (grant \#12002011001-P7).

\section{Author Contributions}

Bruno Ferezim Morales: Substantial contribution in the concept and design of the study, contribution to data collection, analysis and interpretation, contribution to manuscript preparation, contribution to critical revision, adding intellectual content.

Rafaela Priscila Ota: Substantial contribution in the concept and design of the study, contribution to data collection, analysis and interpretation, contribution to manuscript preparation, contribution to critical revision, adding intellectual content.

Victória Dandara Pereira e Silva: Contribution for data collection, analysis and interpretation, contribution to critical revision, adding intellectual content.

Cláudia Pereira de Deus: Substantial contribution in the concept and design of the study, contribution for data collection, contribution to critical revision, adding intellectual content.

\section{Conflicts of interest}

The authors declare that they have no conflict of interest related to the publication of this manuscript.

\section{References}

ANDRADE, M.C., JÉGU, M. \& GIARRIZZO, T. 2016. A new large species of Myloplus (Characiformes, Serrasalmidae) from the Rio Madeira basin, Brazil. ZooKeys 571:153-167.

ANJOS, H.D.B., ZUANON, J., BRAGA, T.M.P \& SOUSA, K.N.S. 2008. Fish, upper Purus River, state of Acre, Brazil. Check List 4(2):198-213.

ARAGÃO, L.P. 1984. Contribuição ao estudo da biologia do aruanã, Osteoglossum bicirrhosum Vandelli 1829, do lago Janauacá - estado do Amazonas, Brasil. I - Desenvolvimento e alimentação larval (Osteichtys Osteoglossiformes). Ciênc. Agron. 15:7-17.

ARMBRUSTER, J.W. 2004. Phylogenetic relationships of the suckermouth armoured catfishes (Loricariidae) with emphasis on the Hypostominae and the Ancistrinae. Zool. J. Linnean Soc. 141:1-80.

BARTHEM, R.B. \& FABRÉ, N.N. 2003. Biologia e diversidade dos recursos pesqueiros da Amazônia. In A pesca e os recursos pesqueiros na Amazônia brasileira (M.L. Rufino, ed.). Pro-Várzea, Manaus, p.11-55

BATISTA, V.S. 1998. Distribuição, dinâmica da frota e dos recursos pesqueiros da Amazônia Central. Tese de Doutorado, Universidade do Amazonas, Manaus.

BATISTA, V.S. 2003. Caracterização da frota pesqueira de Parintins, Itacoatiara e Manacapuru, estado do Amazonas. Acta Amazon. 33(2):291-302.

BETANCUR-R, R., WILEY, E.O., ARRATIA, G., ACERO, A., BAILLY, N., MIYA, M., LECOINTRE, G. \& ORTÍ, G. 2017. Phylogenetic classification of bony fishes. BMC Evol. Biol. 17:162.

BRITSKI, H.A. \& BIRINDELLI, J.L.O. 2008. Description of a new species of the genus Leporinus Spix (Characiformes: Anostomidae) from the rio Araguaia, Brazil, with comments on the taxonomy and distribution of $L$. parae and L. lacustris. Neotrop. Ichthyol. 6(1):45-51.

CASTILLO, B.T.D., MARÍN, C.P. \& KOO, F.C. 2012. Hábitos alimentícios de la Arahuana Osteoglossum bicirrhosum (Cuvier, 1829) en la Cuenca Medio del río Putumayio - el estrecho, Loreto, Perú. Cienc. Amazon. (Iquitos) 2:17-26.

CLARO-GARCÍA, A., VIEIRA, L.J.S., JAHDULI, L.R., ABRAHÃO, V.P. \& SHIBATTA, O.A. 2013. Fishes (Osteichthyes: Actinopterygii) from igarapés of the rio Acre basin, Brazilian Amazon. Check List 9(6):1410-1438.

CRAMPTON, W.C. 2011. An Ecological Perspective on Diversity and Distributions. In Historical Biogeography of Neotropical Freshwater Fishes (J. Albert, ed.). Los Angeles: University of California Press, p.165-189.

DAGOSTA, F.C.P. \& DE PINNA, M. 2017. Biogeography of Amazonian fishes: deconstructing river basins as biogeographic units. Neotrop. Ichthyol. 15(3):e170034.

DAGOSTA, F.C.P. \& DE PINNA, M. 2019. The fishes of the Amazon: distribution and biogeographical patterns, with a comprehensive list of species. Bull. Am. Mus. Nat. Hist. (431):1-163.

DE DEUS, C.P., SILVEIRA, R. \& PY-DANIEL, L.H.R. 2003. Piagaçu-Purus: bases científicas para criação de uma Reserva de Desenvolvimento Sustentável. Manaus, IDSM.

DUARTE, C.; RAPP PY-DANIEL, L.H. \& de DEUS, C.P. 2010. Fishes assemblages in two sandy beaches in lower Purus river, Amazonas, Brazil. Iheringia Sér. Zool. 100(4):319-328.

FEARNSIDE, P.M., ALENCASTRO-GRAÇA, P.M.L., KEIZER, E.W.H., MALDONADO, F.D., BARBOSA, R.I. \& NOGUEIRA, E.M. 2009. Modelagem de desmatamento e emissões de gases de efeito estufa na região sob influência da rodovia Manaus-Porto Velho (BR-319). Rev. Bras. de Meteorol. 24(2):208-233.

FERNANDES, C., PODOS, J. \& LUNDBERG, J.G. 2004. Amazonian Ecology: Tributaries Enhance the Diversity of Electric Fishes. Science. 305:19601962. 
FERRARIS JR., C.J., DE SANTANA, C.D. \& VARI, R.P. 2017. Checklist of Gymnotiformes (Osteichthyes: Ostariophysi) and catalogue of primary types. Neotrop. Ichthyol. 15(1):1-44.

GOULDING, M. 1980. The fishes and the forest: Explorations in Amazonian natural history. California State: University of California Press, Berkeley.

GOULDING, M., BARTHEM, R. \& FERREIRA E.J.G. 2003. The Smithsonian Atlas of the Amazon. Washington: Smithsonian Books, London.

HOORN, C. \& WESSELINGH, F.P. 2010. Introduction: Amazonia, landscape and species evolution. In Amazonia, landscape and species evolution: A look into the past (C. Hoorn \& F.P. Wesselingh, eds.). Oxford: Blackwell Publishing, p.1-6.

IPI. 2010. Plano de Gestão Reserva de Desenvolvimento Sustentável PiagaçuPurus. Volume I. (www.piagacu.org.br/wp-content/uploads/2011/06/Planode-Gest\%C3\%A3o-RDS-PP-2010_vol.- I.pdf). (Last access in 4/03/2019).

JUNK, W.J., BAYLEY, P.B. \& SPARKS, R.E. 1989. The flood pulse concept in river-floodplain systems, p. 110-127. In Proceedings of the International Large River Symposium (D.P. Dodge, ed.). Can. Spec. Publ. Fish. Aquat. Sci. 106, p.110-127.

KULLANDER, S.O. \& FERREIRA, E.J.G 2006 A review of the South American cichlid genus Cichla, with descriptions of nine new species (Teleostei: Cichlidae). Ichthyol. Explor. Freshw. 17(4):289-398.

LAMONTE, F.R. 1935. Fishes from rio Juruá and rio Purus, Brazilian Amazonas. Am. Mus. Novit. (784):1-8.

LIMA, F.C.T. \& RIBEIRO, A.C. 2011. Continental-scale tectonic controls of biogeography and ecology. In Historical biogeography of Neotropical freshwater fishes (J.S. Albert \& R.E. Reis, eds). Los Angeles: University of California Press, p.145-64.

LITTMANN, M.W., AZPELICUETA, M.M., VANEGAS-RIOS, J.A. \& LUNDBERG, J.G. 2015. Holotype-based validation, redescription and continental-scale range extension of the South American catfish species Hypophthalmus oremaculatus Nani and Fuster, 1947, with additional information on Hypophthalmus edentatus Spix and Agassiz, 1829 (Siluriformes, Pimelodidae). P. Acad. Nat. Sci. Phila. 164(1):159-176.

LOWE-MCCONNELL, R.H. 1999. Estudos Ecológicos de Comunidades de Peixes Tropicais. Brazil: São Paulo. Editora da Universidade de São Paulo (EDUSP).

LOWRY, D., WINTZER, A.P., MATOTT, M.P., WHITENACK, L.B., HUBER, D.R., DEAN, M., \& MOTTA, P.J. 2005. Aerial and aquatic feeding in the silver arawana, Osteoglossum bicirrhosum. Environ. Biol. Fishes. 73:453462.

LUJAN, N.K., ARMBRUSTER, J.W., LOVEJOY, N.R. \& LÓPEZFERNÁNDEZ, H. 2015. Multilocus molecular phylogeny of the suckermouth armored catfishes (Siluriformes: Loricariidae) with a focus on subfamily Hypostominae. Mol. Phylogenet. Evol. 82(pt. A):269-288.

MATEUSSI, N.T.B., OLIVEIRA, C. \& PAVANELLI, C.S. 2018 Taxonomic revision of the Cis-Andean species of Mylossoma Eigenmann \& Kennedy, 1903 (Teleostei: Characiformes: Serrasalmidae). Zootaxa. 4387 (2):275-309.

MCCLANAHAN, T.R., GLAESEL, H., RUBENS, J. \& KIAMBO, R. 1997. The effects of traditional fisheries management on fisheries yields and the coral-reef ecosystems of southern Kenya. Environ. Conserv. 24:105-120.

MELO, E.C. Fatores de controle dos fluxos fluviais de material em suspensão em diferentes cenários climáticos na bacia do rio Solimões. 2012. Tese de Doutorado, Instituto Nacional de Pesquisas da Amazônia, Manaus.

MENEZES, N.A. \& GÉRY, J. 1983. Seven new acestrorhynchin characid species (Osteichthyes, Ostariophysi, Characiformes) with comments on the systematics of the group. Rev. Suisse Zool. 90(3):563-592.
MIRANDE, J.M. 2018. Morphology, molecules and the phylogeny of Characidae (Teleostei, Characiformes). Cladistics, 2018:1-19.

PETRETE JR., M. 1978. Pesca e esforço de pesca no estado do Amazonas. II. Locais e aparelhos de captura e estatística de desembarque. Acta Amazon. 8(Supl. 2):1-54.

QUEIROZ, H.L. \& CRAMPTON, W.G.R. 1999. Estratégias para manejo dos recursos pesqueiros em Mamirauá. Brasília, DF.

QUEIROZ, L.J., TORRENTE-VILARA, G., OHARA, W.M., ZUANON, J., PIRES, T. \& DÓRIA, C.R.C. 2013. Peixes do Rio Madeira. São Paulo: Dialeto Latin American Documentary.

RAMIREZ, J.L., BIRINDELLI, J.L.O. \& GALETTI JR., P. M. 2017. A new genus of Anostomidae (Ostariophysi: Characiformes): Diversity, phylogeny and biogeography based on cytogenetic, molecular and morphological data Mol. Phylogenet. Evol. 107:308-323.

RAPP PY-DANIEL, L.H. \& DE Deus, C.P. 2003. Avaliação preliminar da ictiofauna e comentários sobre a pesca no baixo Rio Purus. In: PiagaçuPurus: Bases científicas para a criação de uma Reserva de Desenvolvimento Sustentável (C.P de Deus, R. Silveira \& L.H. Rapp-Py-Daniel, eds.). Instituto de Desenvolvimento Sustentável Mamirauá, Tefé, Amazonas, Brasil, p.31-47.

REIS, R.E., ALBERT, J.S., DI DARIO, F., MINCARONE, M.M., PETRY, P. \& ROCHA, L.A. 2016. Fish biodiversity and conservation in South America. J Fish Biol. 89(1):12-47.

RIBEIRO, F.R.V., RAPP PY-DANIEL, L.H. \& WALSH, S.J. 2017. Taxonomic revision of the South American catfish genus Ageneiosus (Siluriformes: Auchenipteridae) with the description of four new species. J. Fish Biol. 90(4):1388-1478.

SAINT-PAUL, U., ZUANON, J.A.S., CORREA, M.A.V., GARCÍA, M., FABRÉ, N.N., BERGER, U., \& JUNK, W.J. 2000. Fish communities in central Amazonian white-and Blackwater floodplains. Environ. Biol. Fishes. 57:235-250.

SANTOS, G.M., FERREIRA, E.J.G. \& ZUANON, J.A.S. 2006. Peixes comerciais de Manaus. Manaus: Ibama/AM, ProVárzea.

SILVANO, R.A.M., RAMIRES, M., ZUANON, J. 2009. Effects of fisheries management on fish communities in the floodplain lakes of a Brazilian Amazonian Reserve. Ecol. Freshw. Fish. 18:156-166.

SIOLI, H. 1984. The Amazon: limnology and landscape ecology of a mighty tropical river and its basin. Dordrecht: Dr. W. Junk Publishers, Monographiae Biologicae.

SOARES-FILHO, B.S., NEPSTAD, D., CURRAN, L., VOLL, E., CERQUEIRA, G., GARCIA, R.A., AZEVEDO-RAMOS, C., MCDONALD, A., LEFEBVRE, P. \& SCHLESINGER, P. 2006. Modeling conservation in the Amazon basin. Nature, 440:520-523.

VERBA, J.T., BORGES, M.L.O., SILVA, M.N.F., PINTO, L.C. \& RABELLO NETO, J.Q. 2018. Mice on menu: Opportunistic feeding behaviour of the Amazonian silver arowana Osteoglossum bicirrhosum. J. Fish Biol. 93:132-133.

VIEIRA, M.A.R.M., MUHLEN, E.M. \& SHEPARD JR., G.H. 2015. Participatory Monitoring and Management of Subsistence Hunting in the Piagaçu-Purus Reserve, Brazil. Conserv. Soc. 13(3):254-264.

WINEMILLER, K.O. \& JEPSEN, D.B. 1998. Effects of seasonality and fish movement on tropical river food webs. J. Fish Biol. 53:267-296.

ZARSKE, A. \& GÉRY, J. 2008. Revision der neotropischen Gattung Metynnis Cope, 1878. Beschreibung zweier neuer Arten und zum Status von Metynnis goeldii Eigenmann, 1903 (Teleostei: Characiformes: Serrasalmidae). Vertebr. Zool. 58(2):173-196. 